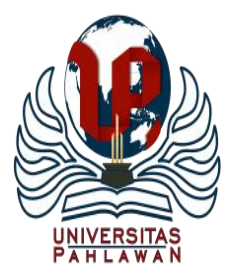

Edukatif : Jurnal Ilmu Pendidikan Volume 3 Nomor 5 Tahun 2021 Halm 2819 - 2826 EDUKATIF: JURNAL ILMU PENDIDIKAN

Research \& Learning in Education

https://edukatif.org/index.php/edukatif/index

\title{
Pengembangan Media Pembelajaran Flipbook Digital di Sekolah Dasar
}

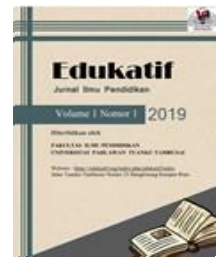

\author{
Widya Nindia Sari ${ }^{1 凶}$, Mubarak Ahmad ${ }^{2}$
}

Universitas Muhammadiyah Prof. Dr. Hamka, Indonesia ${ }^{1,2}$

E-mail : widyanindya24@gmail.com ${ }^{1}$, mubarak@uhamka.ac.id ${ }^{2}$

\begin{abstract}
Abstrak
Kurangnya antusias dan pemahaman murid dalam mempelajari IPS disebabkan minimnya variasi media pembelajaran yang digunakan oleh pendidik sehingga menyebabkan siswa tidak antusias dan kurang memahami materi dalam proses pembelajaran. Riset ini bertujuan untuk meningkatkan produk media flipbook digital untuk mata pelajaran IPS kelas IV materi indahnya keragaman di negeriku. Riset ini menggunakan metode Research and Development (R\&D), mempunyai tahapan: 1) Analyse, 2) Design, 3) Development, 4) Implementation, 5) Evaluation. Tempat pengamatan dilakukan di SDS Kresna Cililitan. Pengumpulan informasi dilakukan dengan cara penilaian angket dari pakar media dan pakar materi juga angket responden dari partisipan pendidik. Hasil pengembangan produk merupakan media pendidikan flipbook digital pembelajaran IPS materi indhanya keragaman di negeriku. Hasil riset validasi pakar media didapatkan persentase sebesar 86.6\% dengan kategori "sangat layak", hasil penilaian pakar materi didapatkan persentase sebesar $90.6 \%$ dikategorikan "sangat layak. Hasil spekulasi siswa pada uji kelompok kecil sebesar 86.80\%, dan uji kelompok besar didapatkan persentase sebesar $87.40 \%$, sehingga media tersebut dinyatakan "sangat layak". Dapat disimpulkan dari perolehan penilaian bahwa media flipbook digital pada bidang IPS materi indahnya keragaman di negeriku kelas IV sangat layak diaplikasikan untuk dijadikan sarana pembelajaran.
\end{abstract}

Kata Kunci: flipbook digital, pengembangan, media pembelajaran.

\begin{abstract}
The lack of enthusiasm and understanding of students in studying social studies is due to the lack of variety of learning media used by educators, causing students to be unenthusiastic and lack understanding of the material in the learning process. This research aims to improvemedia products digital flipbook for class IV social studies subjects regarding the beauty of diversity in my country. This research uses themethod Research and Development (R\&D), has stages: 1) Analysis, 2) Design, 3) Development, 4) Implementation, 5) Evaluation. The place of observation was at SDS Kresna Cililitan. Information collection was carried out by means of a questionnaire assessment from media expert and material expert as well as respondent questionnaires from educator participants. The result of product development is aeducational media for digital flipbook social studies learning material, the beauty of diversity in my country. The results of the media expert validation research obtained a percentage of $86.6 \%$ with the "very feasible" category, the result of the material expert assessment obtained a percentage of $90.6 \%$ categorized as "very feasible". The result of student speculation in the small group test were $86.80 \%$, and the large group test obtained a percentage of $87.4 \%$, so the media was declared "very feasible". It can be concluded from the assessment that media digital flipbook in the social studies field is the beauty of diversity in my country, class IV very feasible to be applied as a learning tool.
\end{abstract}

Keywords: digital flipbook, development, learning media.

Copyright (c) 2021 Widya Nindia Sari, Mubarak Ahmad

$\triangle$ Corresponding author

Email : widyanindya24@gmail.com

DOI : https://doi.org/10.31004/edukatif.v3i5.1012

ISSN 2656-8063 (Media Cetak)

ISSN 2656-8071 (Media Online) 
2820 Pengembangan Media Pembelajaran Flipbook Digital di Sekolah Dasar-Widya Nindia Sari, Mubarak Ahmad

DOI : https://doi.org/10.31004/edukatif.v3i5.1012

\section{PENDAHULUAN}

Setiap manusia membutuhkan pendidikan untuk bisa mengembangkan potensi di dalam dirinya dan dengan pendidikan diharapkan dapat membantu segala persoalan social di tengah masyarakat. Pendidikan bertujuan mempersiapkan pelajar untuk meneruskan kelangsungan hidupnya dimasyarakat. Dalam proses mendidik tentunya akan ada metode pengajaran yang dijalankan oleh guru dan peserta didik itu sendiri. Oleh karena itu dengan adanya perkembangan teknologi pendidik butuh menggunakan teknologi yang tumbuh dikala ini buat dijadikan media pendidikan dalam proses belajar mengajar. Salah satu komponen yang berkaitan dengan perkembangan teknologi dalam Pendidikan adalah media pembelajaran. Menurut Ruth Lautfer (dalam Tafonao, 2018) media pembelajaran merupakan perlengkapan bantu mengajar untuk guru buat mengantarkan modul pengajaran serta tingkatan atensi siswa dalam proses pendidikan, dengan begitu lewat media pendidikan dapat membuat proses belajar mengajar lebih efisien serta efektif dan terjalin ikatan baik antara guru dengan siswa. Tidak hanya itu media sanggup berfungsi dalam menanggulangi kebosanan dalam proses pembelajaran. Maka dari itu pendidik dituntut dapat membagikan motivasi sarana yang tidak cuma ada di dalam kelas namun pula yang terdapat di luar kelas, bila perihal itu dimanfaatkan dengan benar tujuan pendidik hendak tercapai.

Senada dengan penjelasan di atas, peneliti melakukan wawancara bersama wali kelas IV SDS Kresna Cililitan. Kami melakukan perbincangan dalam pertemuan tersebut untuk mengetahui hambatan dalam belajar partsipan pendidik kelas IV, dari informasi yang telah didapatkan yaitu adanya rasa jenuh dan kesulitan memahami materi bilamana proses pengajaran IPS. Wali kelas IV ini juga mengatakan, dalam proses pembelajaran berjalan rata-rata terlampau pelajar yang kurang memahami modul yang diinformasikan oleh pendidik, terutama pada pembelajaran Ilmu Pengetahuan Sosial pembahasan indahnya keragaman di negeriku. Oleh karena itu maka dilakukan pengembangan produk media pembelajaran yang berupaya buat memudahkan pelajar agar menguasai modul pendidikan dan meningkatkan semangat siswa dalam mengikuti kegiatan pembelajaran. Peneliti menyampaikan informasi kepada tenaga pendidik bahwa media pembelajaran flipbook digital akan membantu pendidik pada saat prosos pembelajaran dilakukan.

Swasono, pembelajaran IPS ialah bidang pembelajaran yang wajib diinformasikan pada pelajar khususnya siswa SD. IPS sebagai bidang pendidikan, bukan Cuma membekali murid dengan pengetahuan social, namun lebih jauh daripada itu dengan berusaha membina serta mengembangkan murid menjadi SDM Indonesia (Budiarti, 2015). Pelajaran IPS bertujuan memberikan kesempatan untuk murid supaya dapat mengambil bagian dan dapat berperan serta dalam kehidupan social, mampu menolong siswa dalam mengembangkan ketrapilan untuk mencari dan mengolah dan memproses informasi.Bidang IPS ialah nama bidang yang berdiri selaku integrase konsep disiplin ilmu social, humaniora, sains apalagi bermacam isu serta permasalahan sosial kehidupan (Uno \& Ma'ruf, 2016) selaras dengan Somantri (Budiarti, 2015). Arah pembelajaran IPS secara konseptual wajib dilihat dari istilah yang digunakan di Negara asalnya ialah social stuies serta citizenship aducation ataupun civic education. Pembelajaran IPS mempunyai sudut pandang yang berbeda-beda, bila pembelajaran IPS ditatap selaku social studies, hingga pembelajaran IPS mempunyai tujuan dalam mengkaji masalah-masalah social pada biasanya serta kehidupan manusia, hingga dari itu partisipan didik mempunyai pengetahuan yang logis, lengkap serta objektif pula didukung dengan data serta kenyataan yang terjalin dengan begitu pelajar bias mengambil keputusan secara tepat. Namun jika pelajaran IPS dianggap kalau citizenship aducation ataupun civic education, lantas pendidikan IPS memiliki tujuan untuk mewujudkan siswa jadi masyarakat Negara yang baik sehingga partisipan didik sanggup berfungsi aktif serta efektif dalam kehidupan warga yang demokratis, Pramono (dalam Aditya, 2018). Dengan begitu siswa membutuhkan media pembelajaran flipbook digital untuk mengatasi masalah dalam proses pembelajaran. 
Menurut Warista (dalam Kodi et al., 2019) media flipbook mempunyai keunggulan dibandingkan media pembelajaran lainnya, karena pada media flipbook ini bukan hanya menyajikan gabungan teks tetapi juga berupaya memasukan animasi, video, suara dan lain sebagainya. Sanaky mengatakan flipbook dapat dikelompokan media sound slide yang merupakan jenis dari media audio-visual (Amanullah, 2020). Sedangkan teknologi digital sendiri termasuk teknologi yang sudah tidak memakai kekuatan manusia atau manual. Digital ialah sejenis metode yang rumit dan fleksibel sehingga membuatnya menjadi sesuatu yang pokok dalam kehidupan manusia. Digital merupakan suatu konsep pemahaman dari perkembangan zaman mengenai semua yang bersifat manual menjadi otomatis dan dari semua yag bersifat rumit menjadi ringkas (Aji, 2016). Dapat disimpulkan bahwa flipbook digital adalah media yang disusun secara sistematis yang berisikan materi berupa teks, obyek, maupun suara yang kemudian disajikan dalam format digital yang didalamnya mempunyai unsur multimedia sehingga membuat pengguna lebih interaktif dengan media.

Berdasarkan hasil observasi pada kelas IV SDS Kresna Cililitan dihasilkan data bahwa, dalam pembelajaran IPS siswa merasa jenuh sehingga kurang antusias dan kurangnya pemahaman pada proses pembelajaran maka dari itu tujuan proses pembelajaran belum tercapai. Dalam perkara tersebut guru perlu melakukan variasi dan perubahan dalam proses pembelajaran dengan lebih kreatif. Oleh karena itu peneliti tergiring untuk menciptakan bahan ajar baru berupa flipbook digital pada pembelajaran IPS. Dengan penggunaan media flipbook digital diharapkan dapat membantu tercapainya tujuan pembelajaran.

Pada penelitian sebelumnya oleh (Hayati et al., 2015) pembelajaran dengan media flipbook materi fisika memiliki dampak yang positif yaitu terampil mengoptimalkan hasil belajar peserta didik selaras dengan hasil penelitian (Andri \& Yeni, n.d.). Kemudian pada penelitian (Kodi et al., 2019) menyatakan bahwasannya media yang dikembangkan secara menyeluruh layak digunakan dalam kegiatan pembelajaran sehingga media pembelajaran ini berhasil meningkatkan prestasi belajar siswa sesuai dengan ketuntasan belajar yang diperoleh siswa, pelitian ini selaras dengan (Putri et al., 2020). Hasil dari penelitian (Jauh et al., 2021) menyatakan bahwa media yang dikembangkan layak untuk dijadikan pendukung pembelajaran sekaligus menarik semangat peserta didik, hasil penelitian ini selaras dengan (Hayati et al., 2015)(Rahmawati et al., 2017). Sedangkan pada penelitian yang dilakukan oleh (Meidita \& Susilowibowo, 2021) selaras dengan (Anandari et al., 2019) menyimpulkan bahwa hasil pengembangan media flipbook dinyatakan layak untuk membangkitkan motivasi belajar serta menurunkan tingkat kebosanan dalam proses pembelajaran.

Penelitian ini juga menggunakan media pembelajaran flipbook digital yang bertujuan untuk meningkatkan antusias dan pemahaman murid. Flipbook digital ialah media yang sangat bermanfaan bagi siswa maupun pendidik, maka penelitian ini nantinya akan di uji dengan kelayakan Pengembangan Media Pembelajaran Flipbook Digital Pada Materi Indahnya Keragaman di Negeriku Kelas IV SD.

\section{METODE PENELITIAN}

Penelitian dilaksanakan di SDS Kresna Cililitan. bentuk riset yaitu pengembangan ataupun dengan kata lain Research and development (R\&D). Memakai model pengembangan ADDIE adalah 1) analyze merupakan menganalisis kebutuhan, mengetahui masalah dan menentukan tujuan. 2) design ialah perumusan tujuan umum yang dapat diukur, mengklasifikasikan pembelajar menjadi beberapa tipe, memilih aktifitas pembelajar dan memilih media. 3) development ialah sesi buat mempersiapkan materi buat pembelajar serta pengajar cocok dengan spesifikasi produk yang hendak di kembangkan. 4) implementation merupakan tahap penggunaan produk pengembangan untuk diaplikasikan dalam proses pembelajaran yang sudah didesain sedemikian rupa pada tahap desain. 5) and evaluation yaitu pengembang melaksanakan klarifikasi informasi yang telah didapat dari hasil angket berbentuk reaksi dari partisipan didik, dan terhadap kompetensi, pengetahuan serta perilaku yang wajib dimiliki oleh partisipan didik sehabis menjajaki aktivitas pendidikan. Pada metode penelitian ini diaplikasikan untuk menghasilkan produk tertentu dan men guji keefektifan produk 
2822 Pengembangan Media Pembelajaran Flipbook Digital di Sekolah Dasar-Widya Nindia Sari, Mubarak Ahmad

DOI

: https://doi.org/10.31004/edukatif.v3i5.1012

tersebut. Tahapan-tahapan tersebut terdapat pada gambar 1 yang merupakan alur dari pengembangan $R \& D$ pada model ADDIE.

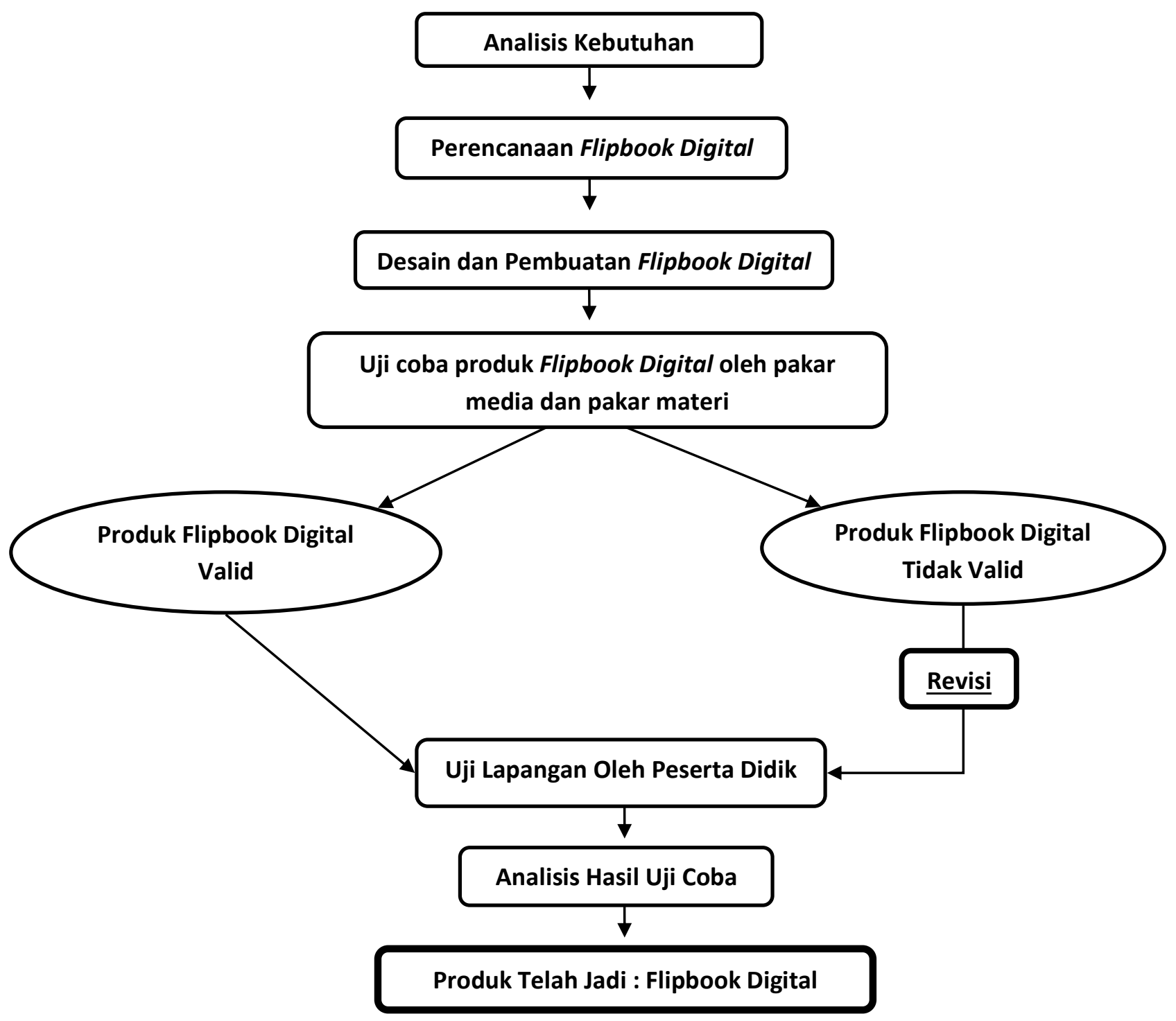

Gambar 1 Prosedur Pengembangan Flipbook Digital Model ADDIE

Pada teknik validasi kelayakan media dalam penelitian media flipbook digital diperoleh dari angket dengan cara penskoran instrument penelitian yang nantinya diisi oleh para pakar yaitu validasi pakar media dan pakar materi. Dibawah ini merupakan tabel penilaian :

Tabel 1 Penskoran Instrumen Penelitian

\begin{tabular}{l|ccccc}
\hline Skor & $\mathbf{5}$ & $\mathbf{4}$ & $\mathbf{3}$ & $\mathbf{2}$ & $\mathbf{1}$ \\
\hline Kategori & Sangat Layak & Layak & Cukup Layak & Tidak Layak & Sangat Tidak Layak
\end{tabular}

Setelah menganalisis maka hasil analisis data pada media flipbook digital akan dihitung melalui rumus seperti berikut;

$$
\rho=\frac{f}{N} x 100 \%
$$


2823 Pengembangan Media Pembelajaran Flipbook Digital di Sekolah Dasar- Widya Nindia Sari, Mubarak Ahmad

DOI

Penjelasan :

$\mathrm{P}=$ Presentase Angka

$\mathrm{F}=$ Presentase Frekuensi

$\mathrm{N}=$ Frekuensi Jumlah

Hasil analisis data dari angket para ahli dan angket penilaian siswa pada media flipbook digital diukur menggunakan skala likert, seperti tabel berikut;

Tabel 2 Kriteria Interpretasi Dengan Skala Likert

\begin{tabular}{c|c}
\hline Presentase & Kategori \\
\hline $81 \%-100 \%$ & Sangat Layak \\
$61 \%-80 \%$ & Layak \\
\hline $41 \%-60 \%$ & Cukup Layak \\
$21 \%-40 \%$ & Tidak Layak \\
\hline$<20 \%$ & Sangat Tidak Layak \\
\hline
\end{tabular}

\section{HASIL DAN PEMBAHASAN PENELITIAN}

Tabel 3 Hasil Data Validasi Kelayakan Ahli Media

\begin{tabular}{c|c}
\hline Nama Validator & Niken Dwi Setyaningsih, M.Pd \\
\hline Skor yang diperoleh & 150 \\
Skor maksimal & 175 \\
\hline Rata-rata persentase & $86 \%$ \\
\hline
\end{tabular}

Pada tabel di atas merupakan hasil perhitungan pada penilaian kelayakan oleh pakar media pada produk pengembangan media flipbook digital pembelajaran IPS materi indahnya keragaman di negeriku, hasil skor yang didapatkan 150 dengan skor maksimal sebesar 175 sehingga dapat dipersentasikan menjadi 86\%. Maka hasil interpretasi dengan skala likert dapat disimpulkan bahwa pada produk pengembangan media ini dikategorikan sangat layak.

Tabel 4 Hasil Data Validasi Kelayakan Ahli Materi

\begin{tabular}{c|c}
\hline Nama Validator & Yuli Kurnianingsih, S.Pd \\
\hline Skor yang diperoleh & 68 \\
Skor maksimal & 75 \\
\hline Rata-rata persentase & $91 \%$ \\
\hline
\end{tabular}

Tabel diatas merupakan hasil perhitungan pada penilaian kelayakan dari ahli materi pada pengembangan media flipbook digital pembelajaran IPS, hasil skor yang diperoleh 68 dengan skor maksimal 75 sehingga dapat dipersentasikan menjadi 91\%. Maka dari itu dapat disimpulkan bahwa nilai persentase dikategorikan dengan skala likert produk media pengembangan media ini termasuk dalam kategori sangat layak.

Tabel 5 Hasil Implementasi Uji Kelompok Kecil

\begin{tabular}{c|ccc}
\hline Responden siswa & Skor (Max.50) & Persentase & Kelayakan \\
\hline 1 & 47 & $94 \%$ & Sangat Layak \\
2 & 40 & $80 \%$ & Layak \\
\hline 3 & 40 & $80 \%$ & Layak \\
4 & 40 & $80 \%$ & Layak \\
\hline 5 & 50 & $100 \%$ & Sangat Layak \\
Rata-rata & $217 / 250$ & $86.8 \%$ & Sangat Layak \\
\hline
\end{tabular}


Data di atas merupakan hasil perhitungan dari uji coba kelompok kecil yang menyertakan 5 orang siswa kelas IV. Peneliti memilih jumlah responden sesuai dengan kondisi pandemi yang sedang terjadi di Indonesia. Dari hasil perolehan yang sudah didapatkan dari respon siswa terhadap pengembangan produk flipbook digital ini mendapatkan penilaian dengan rata-rata $86.8 \%$, dan dapat dikategorikan sangat layak.

\begin{tabular}{c|ccc}
\multicolumn{5}{c}{ Tabel 6 Hasil Implementasi Uji Kelompok Besar } \\
\hline Responden Siswa & Skor (Max. 50) & Persentase & Kelayakan \\
\hline 1 & 48 & $96 \%$ & Sangat layak \\
2 & 48 & $96 \%$ & Sangat layak \\
\hline 3 & 45 & $90 \%$ & Sangat layak \\
4 & 39 & $78 \%$ & layak \\
\hline 5 & 50 & $100 \%$ & Sangat layak \\
6 & 36 & $72 \%$ & layak \\
\hline 7 & 40 & $80 \%$ & layak \\
8 & 40 & $80 \%$ & layak \\
\hline 9 & 41 & $82 \%$ & Sangat layak \\
10 & 50 & $100 \%$ & Sangat layak \\
\hline Rata-rata & $437 / 500$ & $87.4 \%$ & Sangat Layak
\end{tabular}

Pada tabel di atas uji coba kelompok besar dilakukan dengan menggunakan media flipbook digital dengan tujuan untuk mengetahui kelayakan dalam pengembangan produk flipbook digital ini. Dari penilaian respon siswa terhadap produk yang dikembangkan mendapatkan hasil $87.4 \%$ merupakan kategori sangat layak.

Dengan terdapatnya media pendidikan yang menarik serta cocok dengan pendidikan hingga hendak menolong siswa menguasai modul dengan gampang. Gagene dan Briggs mengatakan "Media pembelajaran bisa dimaksud sebagai suatu yang digunakan orang untuk menyalurkan pesan" (Antika \& Suprianto, 2016). Kegunaan media pembelajaran ialah memberikan pedoman untuk pendidik supaya mampu mencapai jutuan sehingga dalam menjelaskan materi pembelajaran dengan urutan yang sistematis (Dwijayani, 2019). Pratiwi mengatakan media pembelajaran mampu mendorong siswa untuk mencapai hasil belajar (Novita et al., 2019). Kemudian Joni Purwono, dkk (Antika \& Suprianto, 2016) menjelaskan juga bahwa media pembelajaran memiliki peranan penting dalam menunjang kualitas proses belajar mengajar dan juga dikatakan dapat mempermudah pembelajaran, karena media yang menarik dan menyenangkan akan mempengaruhi pemahaman siswa terhadap materi, sehingga hal tersebut dapat mempengaruhi hasil belajar peserta didik.

Menurut hasil uji kelompok kecil kelas IV SD dengan menggunakan media yang dipakai peneliti membuat siswa lebih mudah untuk memahami pembelajaran IPS materi indahnya keragaman di negeriku dan meningkatkan antusias peserta didik. Pada uji coba kelompok besar pun mengalami peningkatan hasil pembelajaran, dan hal ini dibenarkan oleh guru kelas IV dikarenakan terdapat perbedaan yang sangat jelas, hasil pembelajaran dengan metode ceramah tanpa media pembelajaran di mata pelajaran IPS membuat siswa merasa jenuh dan sulit untuk memahami materi. Maka dengan adanya inovasi baru yaitu penggunaan media flipbook digital sangat membantu pendidik juga sangat bermanfaat untuk murid kelas IV SD dalam kegiatan pembelajaran IPS materi indahnya keragaman di negeriku.

Pada hasil riset ini sejajar dengan penelitian yang sudah diterapkan oleh (Putri et al., 2020) yang berjudul "Pengembangan E-Modul berbasis Kvisoft Maker Perjuangan Para Pahlawan di Kelas IV Sekolah Dasar" menghasilkan dampak yang bagus dalam merubah rasa bosan siswa dan mempermudah pemahaman siswa pada materi perjuangan para pahlawan, dibuktikan dengan meningkatnya hasil belajar siswa. Dan ada beberapa pendapat yang sama dari hasil penelitian dari (Hayati et al., 2015)(Amanullah, 2020)(Ningtyas et al., 2019) (Fauzan et al., 2019)(Adriawati \& Purwanto, 2018). Hubungan dari penelitian tersebut bahwa pengembangan media flipbook digital mata pelajaran IPS kelas IV sangat sepakat untuk meningkatkan 
pemahaman dan juga antusias siswa dalam pembelajaran indahnya keragaman di negeriku. Selain itu penelitiang dilakukan oleh (Kodi et al., 2019) pada penelitian tersebut media flipbook digital mampu mempermudah penyampaian materi untuk siswa, karena dalam media ini terdapat gambar, animasi atau obyek, video dan audio yang berkaitan dengan materi, sehingga mampu mempermudah pemahaman siswa. Akan tetapi pada pengaruh yang disepakati ini terdapat kekurangan dalam pengaplikasian oleh siswa, karena media ini harus diarahkan beberapa kali supaya siswa memahami cara penggunaan media flipbook digital ini, sehingga hasil dapat terlaksanakan dengan baik.

\section{KESIMPULAN}

Pada hasil riset yang sudah dijabarkan, bahwa pengemabangan media pembelajaran flipbook digital mata pelajaran IPS materi indahnya keragaman di negeriku menggunakan pengembangan $R \& D$ model ADDIE yang sudah di uji coba pada siswa kelas IV. Maka hasil dari produk akhir yaitu berupa flipbook digital yang berisikan pembelajatan IPS materi indahnya keragaman di negeriku. Media ini di kembangkan menggunakan adobe flash dan adobe animate. Flipbook digital ini dikembangkan dengan memiliki kualitas yang baik dan layak teruji dari hasil penilaian oleh para pakar, yaitu pakar media dan pakar ahli. Juga media ini sudah di uji coba pada guru maupun siswa. Dengan penjabaran seluruhnya, maka dapat disimpulkan bahwa dalam penelitian ini dapat menghasilkan media flipbook digital mata pelajaran IPS materi indahnya keragaman di negeriku pada kelas IV SD untuk digunakan sebagai srana atau media pembelajaran dalam prosesbelajar mengajar di Sekolah Dasar.

\section{DAFTAR PUSTAKA}

Aditya, P. T. (2018). Pengembangan Media Pembelajaran Matematika Berbasis Web Pada Materi Lingkaran Bagi Siswa Kelas Viii. Jurnal Matematika Statistika Dan Komputasi. Https://Doi.Org/10.20956/Jmsk.V15i1.4425

Adriawati, \& Purwanto, A. (2018). Pengembangan Media Interaktif Menggunakan Flipbook Maker Pro Dan Kemampuan Berpikir Kritis Terhadap Hasil Belajar Materi IPA Tema 2 Udara Bersih Bagi Kesehatan Kelas 5 Pada Kurikulum 2013. Prosiding Seminar Nasional Pendidikan 2018, 45-49. Https://Journal.Unpak.Ac.Id/Index.Php/Proceedings/Article/View/1136

Aji, R. (2016). Digitalisasi, Era Tantangan Media (Analisis Kritis Kesiapan Fakultas Dakwah Dan Komunikasi Menyongsong Era Digital). Islamic Communication Journal, 1(1), 43-54. Https://Doi.Org/10.21580/Icj.2016.1.1.1245

Amanullah, M. A. (2020). Pengembangan Media Pembelajaran Flipbook Digital Guna Menunjang Proses Pembelajaran Di Era Revolusi Industri 4.0. Jurnal Dimensi Pendidikan Dan Pembelajaran, 8(1), 37. Https://Doi.Org/10.24269/Dpp.V0i0.2300

Anandari, Q. S., Kurniawati, E. F., Piyana, S. O., Melinda, L. G., Meidiawati, R., \& Fajar, M. R. (2019). Development Of Electronic Module: Student Learning Motivation Using The Application Of Ethnoconstructivism-Based Flipbook Kvisoft. Jurnal Pedagogik, 06(02), 416-436.

Andri, Y., \& Yeni, L. F. (N.D.). Media Flipbook Terhadap Hasil Belajar Siswa. 1-9.

Antika, Y., \& Suprianto, B. (2016). Pengembangan Media Pembelajaran Berbasis Prezi Sebagai Upaya Meningkatkan Hasil Belajar Siswa Kompetensi Dasar Aplikasi Rangkaian Op Amp Mata Pelajaran Rangkaian Elektronika Di Smk Negeri 2 Bojonegoro. Jurnal Pendidikan Teknik Elektro, 5(2).

Budiarti, Y. (2015). Pengembangan Kemampuan Kreativitas Dalam Pembelajaran. PROMOSI (Jurnal Pendidikan Ekonomi), 3(1), 61-72. Https://Doi.Org/10.24127/Ja.V3i1.143

Dwijayani, N. M. (2019). Development Of Circle Learning Media To Improve Student Learning Outcomes. 
2826 Pengembangan Media Pembelajaran Flipbook Digital di Sekolah Dasar- Widya Nindia Sari, Mubarak Ahmad

DOI : https://doi.org/10.31004/edukatif.v3i5.1012

Journal Of Physics: Conference Series, 1321(2), 171-187. Https://Doi.Org/10.1088/1742$6596 / 1321 / 2 / 022099$

Fauzan, R., Yawati, J., \& Ribawati, E. (2019). Pengembangan Media Flash Flipbook Digital Dalam Pembelajaran Sejarah Sma Materi Sejarah Lokal Geger Cilegon 1888 Di Sma .... ... Sejarah Dan Ilmu Sejarah, 2(2), 30-38. Http://Jurnal.Unsil.Ac.Id/Index.Php/Bihari/Article/View/1279

Hayati, S., Budi, A. S., \& Handoko, E. (2015). Pengembangan Media Pembelajaran Flipbook Fisika Untuk Meningkatkan Hasil Belajar Peserta Didik. Prosiding Seminar Nasional Fisika (E-Jurnal) SNF2015, IV, 49-54.

Jauh, J., Sma, D., \& Sa, K. (2021). Edukatif: Jurnal Ilmu Pendidikan Pengembagan E-Modul Berbasis Digital Flipbook Untuk Mempermudah Pembelajaran. 3(4), 1298-1308.

Kodi, A. I., Hudha, M. N., \& Ayu, H. D. (2019). Pengembangan Media Flipbook Fisika Berbasis Android Untuk Meningkatkan Prestasi Belajar Pada Topik Perpindahan Kalor. Prosiding Seminar Nasional Fisika (E-Jurnal) SNF2015, 1-8.

Meidita, A. C., \& Susilowibowo, J. (2021). Edukatif: Jurnal Ilmu Pendidikan Pengembangan Bahan Ajar EBook Berbasis Flipbook Sebagai Pendukung Pembelajaran Administrasi Pajak Dengan Kompetensi Dasar Pph Pasal 21. 3(5), 2217-2231.

Ningtyas, A. S., Triwahyuningtyas, D., \& Rahayu, S. (2019). Pengembangan E-Modul Bangun Datar Sederhana Berbasis Problem Based Learning (PBL) Menggunakan Aplikasi Kvsoft Flipbook Maker Untuk Siswa Kelas III Ayu. Journal Of Chemical Information And Modeling, 53(9), 1689-1699.

Novita, L., Sukmanasa, E., \& Pratama, M. Y. (2019). Penggunaan Media Pembelajaran Video Terhadap Hasil Belajar Siswa SD. Indonesian Journal Of Primary Education Penggunaan, 3(2), 64-72. Http://Ejournal.Upi.Edu/Index.Php/IJPE/Index

Putri, I. P., Yuniasih, N., Sakdiyah, S. H., \& Malang, U. K. (2020). Pengembangan E-Modul Berbasis Kvisoft Flipbook Maker Perjuangan Para Pahlawan Di Kelas IV Sekolah Dasar. Seminar Nasional PGSD UNIKAMA, 4, 523-530.

Rahmawati, D., Wahyuni, S., \& Yushardi. (2017). Pengembangan Media Pembelajaran Flipbook Pada Materi Gerak Benda Di Smp. Jurnal Pembelajaran Fisika, 6(4), 326-332. Https://Jurnal.Unej.Ac.Id/Index.Php/JPF/Article/View/6213

Tafonao, T. (2018). Peranan Media Pembelajaran Dalam Meningkatkan Minat Belajar Mahasiswa. Jurnal Komunikasi Pendidikan, 2(2), 103. Https://Doi.Org/10.32585/Jkp.V2i2.113

Uno, H. B., \& Ma'ruf, A. R. K. (2016). Pengembangan Media Pembelajaran IPS Berbasis Website Untuk Siswa Kelas VII Madrasah Tsanawiyah Negeri. JTP - Jurnal Teknologi Pendidikan, 18(3), 169-185. Https://Doi.Org/10.21009/Jtp1803.1 